\title{
ORGANIZATION OF BUSINESS GAMES AS AN INTERACTIVE METHOD OF TEACHING FOREIGN LANGUAGES TO STUDENTS OF HEI AQUIRING SPECIALTIES CONNECTED WITH THE TRANSPORT INDUSTRY
}

\author{
Makoviei O. M. ${ }^{1}$, \\ Kharkiv Aviation Institute (KHAI)
}

\begin{abstract}
Problem. In order to train highly skilled specialists, lectures, seminars, laboratories and practical classes, as well as other forms of training, including the business game as an interactive method of teaching foreign languages to students are held. It is noted that when presenting the studying material in a game form, students are active and interested in the results of their educational activities. There is an urgent need for a serious rethink of our representations. Goal. The goal of the given article is to determine the specifics of business games and the possibility of their application in the educational process of HEI in order to intensify the study of foreign languages by students of specialties connected with the transport industry. Methodology. The specificity of the methodological support of the business game, the content and purpose of the game in teaching a foreign language are investigated. It is noted that a business game can help achieve both the educational and developmental goals of the collective activity of students in the process of teaching a foreign language. Results. The factors and the professionally oriented character of the students' specialty for the preparation and conduct of the business game are determined. The essence, specificity and the methodological support of the business game as an important form of training students of transport specialties to provide foreign language communication in higher educational institutions are considered. Originality. The author proposed recommendations for the development and use of business games. Practical value. Interactive teaching methods help to develop skills of professional communication in a foreign language, promote the development of necessary interpersonal communicative qualities. Optimal introduction of role and business games in the educational and extracurricular process is an important and necessary factor in attracting students to independent active acquisition of knowledge, skills and abilities, development of their cognitive activity, formation of the creative personality of students of higher technical educational institutions.
\end{abstract}

Key words: modern teaching methods, business game, functions of business game, methodical provision of business games, organization of business game, interpersonal communicative qualities, forms of training, foreign language communication, cognitive activity.

\section{Introduction}

In order to train highly skilled specialists, lectures, seminars, laboratories and practical classes, as well as other forms of training, including the business game as a problem method in teaching foreign languages to students are held. After all, it should be noted that when presenting the studying material in a game form, students are active and interested in the results of their educational activities.

The business game is one of the most effective means of activation, involving its participants in the game activity due to the content nature of the game situation itself, and capable of causing in them a high emotional and physical stress. In a game it is much easier to overcome difficulties, obstacles, as well as psychological barriers. The game, which is motivated by its nature, relates to cognitive activity and requires its participants to take on the initiative, perseverance, creativity and imagination.

\section{Research objective}

The study shows that stimulating students' steady and long-term interest in learning is very difficult. For this, the solution of both pedagogical and psychological problems is equally required. Psychological problems of university education include socio-psychological climate of groups, factors of improvement of academic achievement, motivation of education, revival of interest in the chosen profession. The psychological approach is differentiated depending on the specialty, but also has general factors for each profile. Such an example can be the learning of the ability to make a decision. The future specialist should not only use specific knowledge, but also be able to integrate them in the decision-making process even in extreme 
conditions. The identification of the potential of a future specialist is intended to improve the learning process $[1, \mathrm{p} .48]$.

In this regard, activating the creative, cognitive activity of students requires the widespread use of problem-based learning, which, in the context of an ever-increasing amount of information is an effective means of achieving solid, profound knowledge and skills. Problem learning forms the independence of the student's position, develops and improves the ability to creative activity. Problem learning helps to transform the learned knowledge into beliefs and to develop an active life position. The best way to solve problem situations in the educational process is to play, which is a group exercise in solving situations that imitate reality. The game is considered as one of the main active forms of educational activity of students.

The goal is to determine the specifics of business games and the possibility of their application in the educational process of higher educational institutions in order to intensify the study of foreign languages by students of specialties connected with the transport industry.

\section{Analysis of recent researches and publications}

The business game is successfully used in teaching foreign languages to students of transport specialties at higher educational institutions (bachelors and masters). It makes it possible to bring the educational process closer to the personal cognitive activity of students. Interactive teaching methods are widely covered in the scientific works of many scholars.

In work [1] the author emphasizes that stimulating students' steady and long-term interest in learning is very difficult. For this, the solution of both pedagogical and psychological problems is equally required. Psychological problems of university education include socio-psychological climate of groups, factors of improvement of academic achievement, motivation of education, revival of interest in the chosen profession. The future specialist should not only use specific knowledge, but also be able to integrate them in the decision-making process even in extreme conditions. The identification of the potential of a future specialist is intended to improve the learning process. In work [2] the author states the fact that it is the business game that enables to identify the potential of a future specialist through creating a situation of choice and decision-making, in which the conditions are similar to the real ones. The new roles of participants allow them to comprehend, experience and master new features. In work [3] the author focuses on the business game as a form of reproducing a subject and social content of future professional activity of a specialist, modeling of those systems of relations that are characteristic of this activity as a whole. Such reproduction is achieved through sign means, models and roles played by other people. According to the author of work [4], the business game script is a verbal (verbal) or a graphic form of substantive content, which reflects the sequence and character of the actions taken by players (students) and the leader (teacher). The stages and operations of the game in most cases are issued in the form of a flowchart. The element of the script is also the description of the conflict or contradiction inherent in the content of the game. In the opinion of the author of work [5], the quality of knowledge gained in the game form largely depends on the authority of the teacher. A teacher who does not have deep and stable contact with group members cannot conduct a business game at a high level

\section{Business game as a model of students' future professional activity}

The business game is the creation of a situation of choice and decision-making, in which the conditions are similar to the real ones. It involves the following roles of participants that allow them to comprehend, experience and master new features. The game contains a specific event or phenomenon that is subject to simulation, and it is allowed to assign the playing time to any period (present, past, or future) [2, p. 67].

Usually, a business game is a model of students' future professional activity. This is an imitation of the managerial, research, pedagogical real activity of the teacher, the head of a certain institution.

The advantage of business games lies in combining both theory and practice, contributing to the formation of professional knowledge and practical skills. Games increase the interest in the subject being studied, as they are accompanied by positive emotions.

Business games are based on the principles of collective labor, practical utility, democracy, publicity, adversity, maximum prowess of those who participate in it, as well as unlimited perspective of creative activity within the business game.

The business game is primarily a "tool" for the development of both theoretical and practical thinking of a specialist: the ability to analyze 
complex production conditions, to perform complex and new professional tasks.

The pedagogical essence of the acting games consists in activating thinking, increasing the autonomy of the future specialist, raising the spirit of creativity in the education, approaching vocational guidance, preparing for further professional practice.

In accordance with this, the purpose of the business game is defined as the form of training organization, namely to form professional skills and abilities of students participating in an active creative process.

Methodical provision of the game implies the availability of the following materials: a prospectus and game parameters, a set of real and game documentation. The degree of detail of methodological recommendations depends on the complexity of the object of imitation, the characteristics of the students' audience, the specifics of the discipline, its goals and objectives.

Taking into account the content and features of teaching a foreign language, one can present the following classification of business games as follows:

- "warm-up games" such as "brain storm", "club of connoisseurs", themed entertaining games; their task is to intensify the game and collectivist motivation, deepen the interests and imagination of the participants, focusing on the non-standard approach to the material being studied;

- situation-role games include: analysis of specific situations and their role play;

- constructive-role, problem-role, discussion games: the purpose of their application is the formation of skills for the acceptance and effective performance of business roles, developing interaction and communication, productive cooperation, participation in the development of collective solutions;

- creative games: it is a collective creativity in the creation of technical and artistic projects; attraction of students to such games contributes to the development of a creative potential, the teaching of initiative, courage, perseverance, and responsibility.

The business game is a form of reproducing a subject and social content of future professional activity of a specialist, modeling of those systems of relations that are characteristic of this activity as a whole. Such reproduction is achieved through sign means, models and roles played by other people [3, p.137].
When properly organized, the student carries out activities that are professional in form, but educational according to their results and the main content.

During the preparation of a business game and in the process of its conduct, each participant has an opportunity for self-affirmation and self-development. The instructor must help the student to take on the most appropriate role, and show him his best qualities that could be revealed during communication.

Business games need to be prepared, taking into account different factors: specifics working material, basic knowledge of students, and peculiarities of their worldview, etc. It is recommended to start with simulation games.

They differ from the business game by less volume and the limited tasks to be fulfilled. Their goal is to give the students an opportunity to consolidate certain skills in a creative environment and focus attention on some important issue, category, law, etc. The task must contain contradictions, that is, the problem element is already laid in the simulation exercise. After doing simulation exercises, one can switch to business games. In the educational process of a higher educational institution it is, rather, a role play, because the students are not acquainted with their specialty in full measure yet.

This method reveals the student's personal potential: each participant can diagnose his capabilities independently, as well as in joint activities with other participants.

By playing a role, entering into conditional relations with other players, the student gains experience and gets new knowledge, develops skills and abilities, forms the experience of business contacts.

A relationship that self-organizes business cooperation, saturates inter-role communication with the ethical and psychological content, adjusts the players to jointly solve problems that arise during the game is established in a business game.

Recommendations concerning the development and use of business games are as follows.

1. Business games need to be used only when a demand for them exists. This is the acquisition of a holistic experience of future professional activities, expanded in time and space.

2. During the development of a game, it is necessary to be guided by the principle of systemicity and take into account its influence on other types of work on informal and professional activity, students, as well as the reaction of other teachers. 
3. In a business game, the subject and the social component of the participants are necessary, therefore preparation of a business game must begin with the analysis of specific production situations and playing roles. It is also necessary to form in students the discussion culture prior to the beginning of the game.

4. The structural components of the business game should be combined so that it does not become either a simulator or a gamble.

5 . The game must be based on the principles of self-regulation. The teacher works before the game, before training, at the end and during the analysis of game results, which requires important preparatory work, theoretical and practical skills of constructing a business game.

6 . The mode of student work in the process of conducting a business game does not fit into the limits of their traditional behavior in the classroom and should obey the logic of the simulated production process.

7. At higher educational institutions, the compact business games designed for 4 hours of practical classes are the most acceptable ones.

When organizing a business game, the teacher must take into account such special features as:

- groups of participants should be small (3-8 people), however an unlimited number of group members is possible;

- each member of the group should know clearly his duties and take into account the time limits;

- analysis of the results of the game must be carried out after its completion.

The general structure of creating a business game includes the following steps:

- preparatory;

- role-play of the simulated situation;

- summing up the results of the game and analyzing its results.

The preparatory stage for organizing a business game involves performing such operations as:

1. Choosing a theme and diagnosing the original situation. The theme of the game can be any section of the topic of a given discipline.

2. Forming a goal and a task, taking into account not only the topic but also the output of the situation. It is important to build a game within a single "situation".

3. Defining the structure, taking into account the purpose, tasks, themes, and the composition of participants.

4. Diagnosing the game qualities of participants in a business game to be sure that the team has developed a positive interpersonal relationship.

5. Diagnosing the objective circumstances and considering the question of where, how, when, under what conditions, and with what subjects the game will be played with.

In the process of preparing a business game, all didactic methods can be applied: explanatory-illustrative, reproductive, problematic teaching, partial investigation, and research one.

You also need to take into account the following methodological requirements:

- the game should be a logical continuation and completion of a particular theoretical theme (section) of a given discipline, a practical addition to studying a discipline in general;

- maximum approximation to real professional conditions;

- creating an atmosphere of search and ease;

- thorough preparation of educational and methodical documentation;

- clearly articulated tasks; certain content and rules of the game;

- identification of possible solutions to a particular problem;

- availability of necessary equipment.

In order to make the business game successful, the teacher must write the script and be sure to familiarize the students with this document so that they could have time to prepare. The business game script is a verbal (verbal) or a graphic form of substantive content, which reflects the sequence and character of the actions taken by players (students) and the leader (teacher). The stages and operations of the game in most cases are issued in the form of a flowchart. The element of the script is also the description of the conflict or contradiction inherent in the content of the game [4, p. 180].

The set of roles and player functions must adequately reflect professional and sociopersonal relations characteristic of the fragment of professional activity modeled in the game. The higher is the professional level of the teacher, the better the set of roles are. The difficult moment in developing a game is a clear distribution of player functions. They must be put together and supplemented by instructions in which, in tables, or in the form of algorithms, the rights, duties and possible actions of the players are listed in a verbal form.

The rules of the game reflect the characteristics of real processes and phenomena, which exist in prototypes of simulated reality in a simplified version. 
In addition, there is another plan of the game - the rules of purely gaming nature; if they are not followed, the game will cease to be a game, turning into a training session type.

Requirements to the game rules are reduced to the following provisions:

- the rules of the game contain restrictions related to the technology of the game, the rules of the game procedures or their elements, the roles and functions of the teacher-leader, evaluation system;

- the rules should not be voluminous, no more than 5-10, they should be presented to the audience on posters or with the help of technical means;

- the nature of the rules should ensure reproduction of the real and business context of the game;

- the rules should be related to the incentive system and instructions for players.

The evaluation system provides control over the decisions that are made, self-control, and provides meaningful evaluation, as well as the competitive character of the game, makes it possible to evaluate the activity and personal qualities of the participants of the game, and consequently the success of the work of the game groups. It should be built first of all as a system of self-evaluation of players, and then as estimates of the teacher-presenter.

The business game is a controlled system, because the game procedure is prepared and adjusted by the teacher. If the game is in the scheduled mode, the teacher may not interfere with gambling, but only observe and evaluate the students' gaming activity. If the actions go beyond the plan and the purpose of the lesson is not achieved, the teacher can adjust the direction of the game and its emotional mood.

Business games as an organizational form have both a negative and a positive impact on the learning process.

Advantages of using business games:

- the goal of the game on a big scale corresponds to the practical needs of students.

This form of organizing the educational process eliminates the differences between the abstract nature of the subject and the real nature of the professional activity:

- the game contributes to deep comprehension of a wide range of problems;

- in the game there are formed professional activities, stereotypes that are easier to overcome, self-esteem is corrected;

- unlike traditional methods that involve dominance over the intellectual sphere, in the game the personality can fully realize his/her abilities;

- the game provokes the inclusion of reflexive processes, provides an opportunity for interpretation, comprehension of the results obtained;

- students are usually satisfied, the educational process is motivated and emotionally rich;

- there is preparation for professional activity, skills and abilities are formed: students learn to apply their knowledge; post-heated discussion contributes to the consolidation of knowledge.

The experience gained in the game may be more productive than gaining in professional activity. This is due to the fact that business games can increase the scope of reality, clearly demonstrate the results of the decisions, provide an opportunity to check alternative decision; the information that a person uses in reality is incomplete, inaccurate, and it is provided for the game, although incomplete, but accurate information that increases the confidence in the results obtained and stimulates the process of assuming responsibility [4, p. 94].

The business game helps to achieve educational, educational and developmental goals of a collective nature, based on familiarizing with the actual organization of work.

The simulated situation should involve ambiguity of decisions, contain elements of uncertainty that provide the problem character of the game and identify the abilities of the players. Direct formulation of the problem or indication

to it is not allowed. At the same time, rules, norms are formulated unambiguously.

Expected efficiency of using business games:

- cognitive: in the process of business game students are introduced to the dialectical methods of studying the problem, organization of the team work, the functions of his/her "position" based on one's own experience;

- educational: in the process of performing a business game, the awareness of membership of each participant is formed; the degree of participation in the work is determined; the relationship of participants is felt when performing common tasks; all issues are discussed collectively; it contributes to the formation of criticality, restraint, respect for the thoughts of others, and attention to comrades in the game;

- developing: in the process of business game, logical thinking, the ability to find answers to questions, speech, speech etiquette, the ability to communicate during the discussion are formed.

The quality of knowledge gained in the game form largely depends on the authority of the 
teacher. A teacher who does not have deep and stable contact with group members can not conduct a business game at a high level $[5,164]$.

If the instructor cannot rely on his students' knowledge, pedagogical skills, human qualities, the game will not achieve the intended result, or vice versa, may have the opposite result. Therefore, only taking into account all the peculiarities of this form of training organization, observance of the requirements and recommendations to its implementation will give a positive result of educational activities.

\section{Conclusions}

The conclusions were formulated based on the research conducted and the prospects of further investigation in the given field.

Thus, such interactive teaching methods help to develop skills of professional (and not only) communication in a foreign language, promote the development of necessary interpersonal communicative qualities: communicative and tolerant, dynamic and flexible behavior, empathy, rationality and orientation towards cooperation. Therefore, optimal introduction of role and business games in the educational and extracurricular process is an important and necessary factor in attracting students to independent active acquisition of knowledge, skills and abilities, development of their cognitive activity, formation of the creative personality of students of higher technical educational institutions.

\section{References}

1. Вербицький А. А., Борисов Н. В. Методичні рекомендації для доведення ділових ігор. Москва. $1990.48 \mathrm{c}$.

2. Дроздова I. П. Наукові основи формування української професійної творчості студентів нефілологічних факультетів вищих навчальних закладів: монографія. Харків, КСАМЕ. 2010. C. 320.

3. Миколаєва С. Ю., Біхіч О. Б., Бражник Н. О. Методика вивчення іноземних мов у серденьких навальних закладах: Підруч. для студентів Вузів. Київ: Ленвіт. 1999. 319 с.

4. Лівінгстон С. Рольова гра в вивченні мови. Лондон. 1983. $94 \mathrm{c.}$.

5. Маковей Р. Г. Самостійна робота як форма навчального процесу в ВНЗ для розробок у внутрішньому професійному рухливому студенті транспортних спеціальностей. Наукові записи Бердянськського державного педагогічного університету. Серія: Педагочні науки. Бердянськ: Видавництво П.П. Лисенко. 2017. C. 164.

\section{References}

1. Verbyts'kyi A. A. (1990). Metodychni rekomendatsiyi dlya provedennya dilovykh ihor [Methodical recommendations for conducting business games]. Pidruch. dlya stud. vuziv, za red. V.I. Borisova. Moskva [in Russian].

2. Drozdova I. P. (2010). Naukovi osnovy formuvannya ukrayins'koyi profesiynoyi movy dlya studentiv nefilolohichnykh fakul'tetiv vyshchykh navchal'nykh zakladiv: [Scientific fundamentals of formatting the Ukrainian professional communication of students of non-philological faculties of higher educational institutions]. Monohrafiya. Harkiv, KSAME [in Ukrainian].

3. Nikolayeva S. Yu. (1999). Metodyka navchannya inozemnykh mov u serednikh navchal'nykh zakladakh: [Methods of teaching foreign languages in secondary schools: Manual for students of higher educational institutions]. Pidruch. dlya stud. vuziv, za red. K. I. Onyshchenko. K.: Lenvit [in Ukrainian].

4. Livingstone C. (1983). Role-play in language learning/C. Livingstone. London.

5. Makovyey R.H. (2017). Samostiyna robota yak forma navchal'noho protsesu u VNZ dlya rozvytku inshomovnoho profesiynoho movlennya studentiv transportnykh spetsial'nostey [The independent work as a form of the educational process at the university for the development of foreign language professional communication of students of transport specialties]. Naukovi zapysky Berdyans'ks'koho derzhavnoho pedahohichnoho universytetu. Seriya: Pedahohichni nauky. Berdyans'k: Vydavnytstvo P. P. Lysenko. [in Ukrainian].

Makoviei Oksana Mykolaivna ${ }^{1}$, TeachingAssistant, Department of Foreign Languages, tel.: +38 097-310-40-19, oxanamakovey@gmail.com,

${ }^{1}$ National Aerospace University (Kharkiv Aviation Institute), 17 Chkalov Str., Kharkiv, 61070, Ukraine.

Організація ділової гри як інтерактивного методу навчання іноземної мови студентів транспортних спеціальностей ВНЗ

Анотація. Визначено сутність, специфіку та методичне забезпечення ділових ігор як важливою формою навчання студентів іншомовному спілкуванню у вищій школі нефілологічного профілю. Досліджено специфіку методичного забезпечення ділової гри, що передбачає наявність навчально-наукових $i$ проектних матеріалів, зміст і мету проведення гри з іноземної мови, а також психолого-соціологічний характер студентської аудиторії. Зазначається, що ділова гра може допомогти досягненню навчальних, виховних і розвивальних иілей у колективній діяльності студентів-нефілологів у процесі навчання іноземної мови. 3'ясовано чинники, зокрема складність й актуальність навчального матеріалу, базовий рівень знань студентів нефілологічного профілю, 
професійно-орієнтований характер фаху студентів, специффіку їхнього світогляду тощчо, щзо дозволяють детально підготувати й провести дiлову гру. Стаття містить аналіз передбачуваної ефективності проведення в студентській аудиторії ділових ігор, підкреслюється їх пізнавальний, виховний, розвивальний, колегіальний характер ци психологічні аспекти, за якими визначається навчальна корисність і дидактична доцільність ділових ігор. Окремо підкреслено, щзо комплектаиія рольових функиій тих, хто беруть участь у грі, має адекватно віддзеркалювати професійні ц̆ соиіально-особистісні відносини, характерні для професійної діяльності, змодельованої у грі. У статті сфокусовано значну увагу неоднозначність і невизначеності результатів гри, щзо забезпечують ї̈ проблемний характер $i$ виявляють здібності та вольові якості гравців. Правильна організація гри допомагає студентам здійснювати діяльність, що є фаховою за напрямом, проте ия діяльність виступає як навчальна $i$ методична виправдана за своїми результатами та загальним пізнавальним змістом. У процесі підготовки ділової гри, проведення й обговорення ї̈ результатів кожен учасник має змогу для самоствердження і самовдосконалення своїх знань, умінь і навичок.

Ключові слова: сучасні методи навчання, ділова гра, функиії ділової гри, методичне забезпечення ділових ігор, організачія ділової гри.
Маковсй Оксана Миколаївна ${ }^{1}$, асистент кафедри іноземних мов, тел .: +38 097-310-40-19, e-mail: oxanamakovey@gmail.com,

${ }^{1}$ Національний аерокосмічний університет (Харківський авіаційний інститут), вул. Чкалова, 17, Харків, 61070, Україна.

Организация деловой игры как интерактивного метода обучения иностранному языку студентов транспортных специальностей вузов

Аннотация. рассматривается сущность, специфика и методологическая поддержка деловой игры как важной формы обучения студентов технических специальностей иноязычному общению в высшей школе. Определены факторы, базовый уровень знаний студентов технического профиля, специфика их кругозора и т.д., что позволяет подготовить и провести деловую игру.

Ключевые слова: современные методы обучения, деловая игра, элементы деловой игры, методологическая обеспечение деловых игр, организация деловой игры.

Маковей Оксана Николаевна ${ }^{1}$, ассистент кафедри иностранных языков, тел.: +38 097-310-40-19, e-mail: oxanamakovey@gmail.com,

${ }^{1}$ Национальный аэрокосмический университет (Харьковский авиационный институт), ул. Чкалова, 17, Харьков, 61070, Украина. 